University of Nebraska - Lincoln

DigitalCommons@University of Nebraska - Lincoln

Faculty Publications from the Harold W. Manter Laboratory of Parasitology

$12-1982$

\title{
Eimeria from Jumping Mice (Zapus spp.): A New Species and Genetic and Geographic Features of $Z$. hudsonius luteus
}

Donald W. Duszynski

University of New Mexico, eimeria@unm.edu

Gary Eastham

University of New Mexico

Terry L. Yates

University of New Mexico

Follow this and additional works at: https://digitalcommons.unl.edu/parasitologyfacpubs

Part of the Parasitology Commons

Duszynski, Donald W.; Eastham, Gary; and Yates, Terry L., "Eimeria from Jumping Mice (Zapus spp.): A New Species and Genetic and Geographic Features of Z. hudsonius luteus" (1982). Faculty Publications from the Harold W. Manter Laboratory of Parasitology. 178.

https://digitalcommons.unl.edu/parasitologyfacpubs/178

This Article is brought to you for free and open access by the Parasitology, Harold W. Manter Laboratory of at DigitalCommons@University of Nebraska - Lincoln. It has been accepted for inclusion in Faculty Publications from the Harold W. Manter Laboratory of Parasitology by an authorized administrator of DigitalCommons@University of Nebraska - Lincoln. 


\title{
EIMERIA FROM JUMPING MICE (ZAPUS SPP.): A NEW SPECIES AND GENETIC AND GEOGRAPHIC FEATURES OF Z. HUDSONIUS LUTEUS
}

\author{
Donald W. Duszynski, Gary Eastham, and Terry L. Yates \\ Department of Biology, The University of New Mexico, Albuquerque, New Mexico 87131
}

ABSTRACT: Of 103 jumping mice (Zapus spp.) examined, 29 (28.2\%) had coccidian oocysts in their feces: one of seven (14\%) Z. trinotatus eureka from Humboldt Co., California; 25 of 60 (42\%) Z. princeps princeps, including seven of 18 (39\%) from Boulder Co., Colorado, and 18 of 42 (43\%) from Santa Fe and Taos cos., New Mexico; and three of $36(8 \%) Z$. h. luteus, including one of one from Sandoval Co., New Mexico, two of 13 (15\%) from Apache Co., Arizona, and none of 22 from Otero and Soccoro cos., New Mexico. Twenty-eight of 29 infected mice had only Eimeria zapi oocysts in their feces; the only Z. h. luteus from Fenton Lake, Sandoval Co., New Mexico, had oocysts of a species which we describe here as new. Sporulated oocysts of Eimeria hudsonii $\mathrm{sp}$. $\mathrm{n}$. from $Z$. h. luteus are elliptical, $20.9 \times 14.4(18-23 \times 13-16) \mu \mathrm{m}$ with ovoid sporocysts $10.5 \times 5.6(8-11 \times 5-$ 7) $\mu \mathrm{m}$. A micropyle cap, polar and substieda bodies were absent, but a micropyle, oocyst and sporocyst residua, and Stieda body were present. Sporozoites have one large posterior refractile body. The oocyst wall has two layers. This is only the second eimerian reported from Zapus spp. The geographic distribution of $E$. zapi closely paralleled genetic and geographic features recently reported within the host taxon $Z$. $h$. luteus.

Since May 1979, we have collected and examined over 3,000 wild mammals from the United States, northern Mexico, Baja California, and Japan. These collections are part of a continuing study designed to understand the evolutionary relationships of certain groups of congeners and conspecifics using pelage, skeletal, morphologic, electrophoretic, karyotypic, and parasite data. Ultimately we hope to be able to relate host genetics and distribution to susceptibility, parasite burdens, and coccidian specificity. This report is the first on the coccidians of one group of these mammals.

We examined four species of Zapus from four states for Coccidia and found two eimerians, Eimeria zapi Gerard, Chobotar, and Ernst, 1977, and a form which we describe here as new.

\section{MATERIALS AND METHODS}

Hosts were killed within a few hours after being live trapped. The abdominal cavity was opened by a longitudinal ventral incision and the intestinal tract, from the duodenum to the anus, was removed. The small intestine was slit lengthwise and placed into a vial of AFA (Humason, 1979) to preserve helminths. The cecum and colon were slit lengthwise and preserved, with their contents, in vials containing $2.5 \%$ aqueous (w/v) $\mathrm{K}_{2} \mathrm{Cr}_{2} \mathrm{O}_{7}$.

Upon return to the laboratory all vials were refrigerated $(4 \mathrm{C})$ until they could be processed and examined. Processing for oocysts consisted of separating fecal contents from cecal-colon tissue by scraping with a scalpel. The fecal- $\mathrm{K}_{2} \mathrm{Cr}_{2} \mathrm{O}_{7}$ mixture from each mouse was placed at $23 \mathrm{C}$ for 7 days in a $15-\mathrm{cm}$ Petri dish.

Received 28 September 1981; revised 6 January 82, 24 May 1982; accepted 6 June 1982.
It was then filtered through 40- and 60-mesh brass screens and aliquots of the filtrate were examined by coverslip flotation with a concentrated sucrose solution (sp. gr. 1.15). Oocysts were measured with an ocular micrometer and photographed with either Panatomic-X or Ilford Pan F 35-mm film within a Zeiss Universal Photomicroscope equipped with both brightfield (Neofluar) and Nomarski-interference $\times 100$ objectives. All measurements are in $\mu \mathrm{m}$ with the ranges in parentheses following the means.

\section{RESULTS}

We examined 103 jumping mice (Zapus spp.) from Arizona (13), California (7), Colorado (18), and New Mexico (65), including $36 Z$. h. luteus, $60 Z$. princeps princeps, and seven $Z$. trinotatus eureka. Only 29 of the 103 mice examined (28.2\%) had coccidian oocysts in their feces at the time they were examined. Of those infected, 28 had only Eimeria zapi oocysts. These were one of seven (14\%) Z. t. eureka from Humboldt Co., California; 25 of 60 (42\%) Z. p. princeps, including seven of 18 (39\%) from Boulder Co., Colorado, and 18 of 42 (43\%) from Santa Fe and Taos cos., New Mexico; and two of 35 (6\%) $Z$. h. luteus, including two of 13 (15\%) from Apache Co., Arizona, and none of 22 from Otero and Soccoro cos., New Mexico. The only Z. h. luteus from Sandoval Co., New Mexico, had oocysts of a species which we describe here as new.

\section{Eimeria hudsonii sp. $\mathbf{n}$.} (Figs. 1-5)

\section{Description}

Oocyst ellipsoid; wall $\sim 1.0$ consisting of two layers, each smooth, colorless and $\sim 1 / 2$ of total wall thickness; micropyle (Fig. 4) at one end, $\sim 3$; micropyle cap and polar body absent; oocyst residuum compact (Fig. 5) 

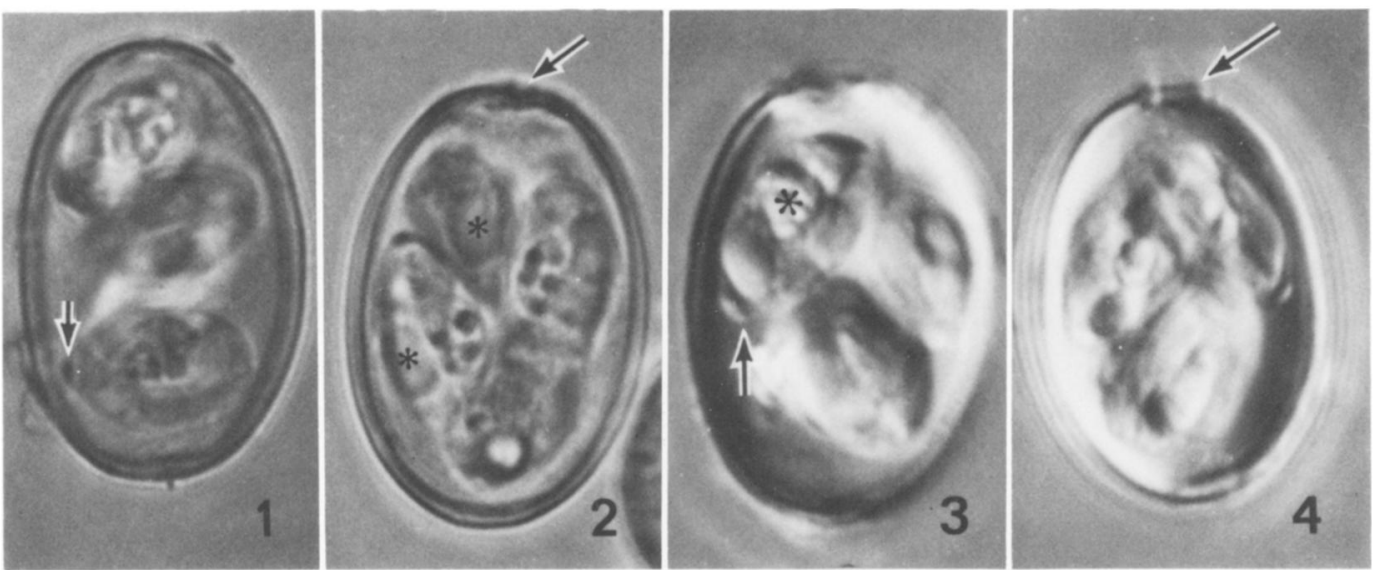

Figures 1-4. Sporulated oocysts of Eimeria hudsonii sp. n. $\times 1,900$. 1, 2. Oocysts in optical cross-section (brightfield). 1. Note Stieda body of sporocyst (arrow). 2. Refractile body of sporozoites (*) is seen in two sporocysts. 3, 4 . Oocysts in optical cross-section (Nomarski). 3. Note sporocyst residuum $\left({ }^{*}\right.$ ) and Stieda body (arrow). 4. Arrow shows micropyle opening not clearly seen under brightfield optics (cf. Fig. 2, arrow).

consisting of one to several homogeneous granules, 3 ; sporulated oocysts $(n=70) 20.9 \times 14.4(18-23 \times$ 13-16) with $\mathrm{L}: \mathrm{W}$ ratio $1.5(1.3-1.6)$; sporocysts ovoid $10.5 \times 5.6(8-11 \times 5-7)$ with $\mathrm{L}: \mathrm{W}$ ratio $1.9(1.7-2.3)$; Stieda body present (Figs. 1, 3); substieda body absent; sporocyst residuum (Fig. 3) a compact mass of 6 to 10 granules, $\sim 3.0$ to 4.5 ; sporozoites with one large refractile body near posterior end (Fig. 2); nucleus sometimes visible in anterior $1 / 2$ of sporozoite (Fig. 5).

\section{Taxonomic summary}

Diagnosis: Only E. zapi has been described previously from Zapus spp. Eimeria hudsonii can easily be distinguished from $E$. zapi in size and shape of the oocyst, number of oocyst walls, texture of the outer oocyst wall, presence of a micropyle and oocyst residuum and absence of polar granule and substieda body.

Host: Zapus hudsonius luteus (Miller, 1911), meadow jumping mouse, Museum of Southwestern Biology, Division of Mammalogy, MSB 41055 (male), K. E. Petersen No. 501, 5 August 1979.

Locality: New Mexico, Sandoval Co., $12.5 \mathrm{mi} \mathrm{N}$. Jémez Springs, near Fenton Lake.

Site of infection: Unknown. Oocysts recovered from feces.

Etymology: The specific name is derived from the specific part of the scientific name of the host.

Remarks: Whitaker (1963) noted that seven of 31 (23\%) Z. hudsonius in central New York had eimerian oocysts, but he did not describe or name the parasite. Gerard et al. (1977) described E. zapi from four of five $Z$. hudsonius caught in southwestern Michigan. To our knowledge there are no other reports of coccidians from Zapus spp. or from their New World (Napaeozapus) or Old World (Eozapus, Sicista) relatives within the Family Zapodidae.

\section{DISCUSSION}

In a brief review of host and site specificity in the Coccidia, Marquardt (1981) pointed out the obvious (but often ignored) truism, "there is a strong genetic component in host specificity" when he noted that certain strains or populations of hosts can be susceptible to a coccidian species whereas other members of the same host species may be completely refractory. In our discussion to follow we will speculate about the host-parasite interrelationship in a way that has been neglected by almost everyone who has done survey work in the past. Namely, we will consider known genetic features of $Z$. h. luteus relative to this host's geographic distribution and geographic isolation because both host genetics and distribution are important factors pertaining to what parasites a particular population of hosts will and can harbor.

The only $Z$. h. luteus population that was found infected with $E$. zapi was the sample from Apache County, Arizona. Reasons for the geographic differences in coccidian infections of the populations of $Z$. h. luteus examined are not known, although the presence of $E$. zapi in the White Mountains (Arizona) population of luteus suggests that at some time in the past the Arizona $Z$. h. luteus may have occurred in sympatry with $Z$. princeps. A number of zoogeographic and ecological considerations support such a hypothesis. Although the Otero and Soccoro counties, New Mexico, populations occur in more typical $Z$. hudsonius habitat, the Apache County, Arizona, population occurs in exemplary $Z$. princeps habitat of dense willow thickets along streams and rivers in the White Mountains (Hafner et al., 


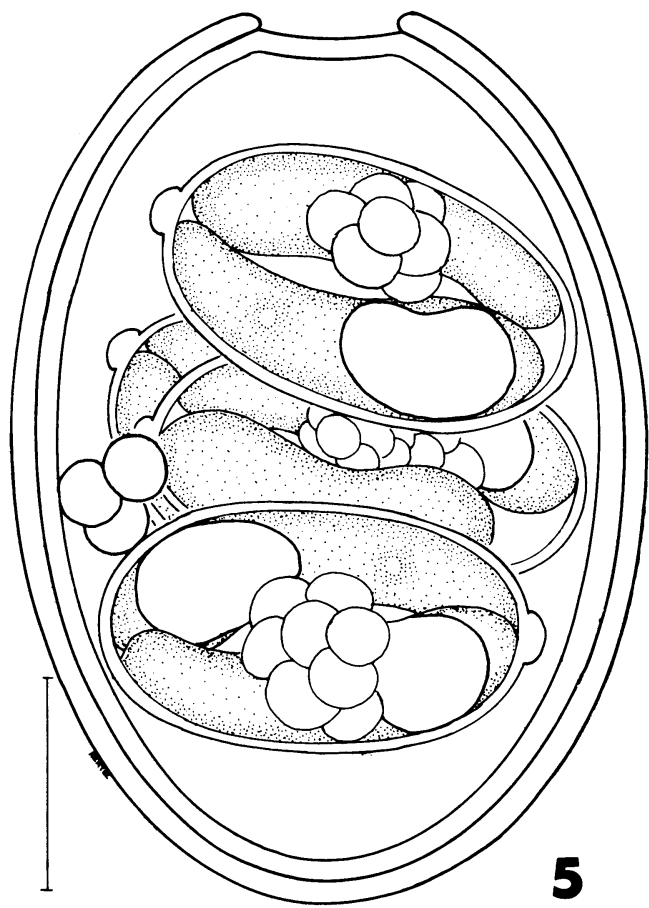

FIGURE 5. Schematic drawing of sporulated oocyst of Eimeria hudsonii. Bar $=5 \mu \mathrm{m}$.

1981). Apparently, glacial periods were not severe enough to drive $Z$. princeps to colonize the southern New Mexico habitats, whereas conditions may have existed west of the continental divide to allow the now relict population of $Z$. $h$. luteus in the White Mountains to contact populations of $Z$. princeps to the north. We believe such contact to be a requisite for infection of $Z$. $h$. luteus with $E$. zapi in this case for a number of reasons. Morphologically E. zapi is distinctive and easily recognized, making the possibility of convergence unlikely. In addition, this parasite has only been reported from the mammalian family Zapodidae making transmission to $Z$. $h$. luteus from another mammalian host equally unlikely. Finally, none of the other luteus populations sampled were infected with E. zapi, although it has been reported from $Z$. hudsonius in more northern populations (Gerard et al., 1977). If E. zapi had been transported to the
White Mountains by the original colonizing stock one would expect it to occur in the New Mexico populations as well, unless some unknown factor has since caused its extinction in those populations.

Our sample size at this time is too small to reach any conclusions about the affinity of the new species, $E$. hudsonii, from the Fenton Lake $Z$. h. luteus sample. It is of interest, however, that the Zapus at Fenton Lake are genically the most divergent of the $Z$. h. luteus that have been examined electrophoretically (Hafner et al., 1981). Perhaps speciation in the genus Eimeria is closely correlated with genetic variation in the host even at the population level. Although speculative, the above scenario relative to $E$. zapi offers an hypothesis of host-parasite co-evolution in this group that can be tested as additional parasite data become available from host taxa in which genetic information is known.

\section{ACKNOWLEDGMENTS}

We are sincerely indebted to Dr. D. J. Hafner and Ms. K. Petersen, Division of Mammalogy, Museum of Southwestern Biology, The University of New Mexico, for collecting the hosts used in this study and to Ms. Lynn Hertel for the line drawing of $E$. hudsonii. This study was supported by NIH Grant 2 S06 RR-08139-07, and by a grant from the Faculty Research Allocation Committee, College of Arts and Sciences, University of New Mexico.

\section{LITERATURE CITED}

Gerard, G., B. Chobotar, and J. V. ERnst. 1977. Eimeria zapi sp. n. from the meadow jumping mouse, Zapus hudsonius Zimmerman in southwestern Michigan. J. Protozool. 24: 362-363.

HafNer, D. J., K. E. Petersen, AND T. L. Yates. 1981. Evolutionary relationships of jumping mice (genus Zapus) of the southwestern United States. J. Mammal. 62: 501-512.

Humason, G. L. 1979. Animal tissue techniques, 4th ed. W. H. Freeman and Co., San Francisco, California, $661 \mathrm{p}$.

MARQUARDT, W. C. 1981. Host and site specificity in the Coccidia: A perspective. J. Protozool. 28: 243-244.

Whitaker, J. O., JR. 1963. A study of the meadow jumping mouse, Zapus hudsonius (Zimmerman), in central New York. Ecol. Monogr. 33: 215-254. 